\title{
Aminoglycoside-resistant enterococci
}

\author{
M. J. BASKER, B. SLOCOMBE, AND R. SUTHERLAND \\ From Beecham Pharmaceuticals Research Division, Brockham Park, Betchworth, Surrey
}

SUMmARY Thirty-four recent clinical isolates of Streptococcus faecalis were tested for sensitivity to amoxycillin, benzylpenicillin, streptomycin, kanamycin, gentamicin, tobramycin, and amikacin. Amoxycillin was two- to four-fold more active than benzylpenicillin and all strains were inhibited by low concentrations of the penicillins. The aminoglycosides were less active against the enterococci than were the penicillins and a significant number of strains were insensitive or relatively insensitive to one or more of the aminoglycosides. Thus, eight (23\%) strains showed a high level of resistance to streptomycin and kanamycin (MIC $>5000 \mu \mathrm{g} / \mathrm{ml}$ ) but were sensitive to gentamicin, tobramycin, and amikacin. In addition, two strains of Strep. faecalis, isolated at different hospitals from patients who had received topical gentamicin therapy, were relatively resistant to gentamicin (MIC 250 to 500 $\mu \mathrm{g} / \mathrm{ml}$ ) and were less sensitive also to the other aminoglycosides. Bactericidal synergy was demonstrated by amoxycillin/aminoglycoside combinations against the enterococci, provided that the test strain of Strep. faecalis was sensitive to the aminoglycoside in the combination. An exception to this was the combination of amoxycillin plus amikacin which was not synergistic against kanamycinresistant strains of Strep. faecalis although these organisms were sensitive to amikacin in the growth inhibition tests. The gentamicin-resistant strains showed variable responses to amoxycillin/aminoglycoside combinations in tests for bactericidal synergy and were generally less sensitive than typical strains of Strep. faecalis.

The aminoglycoside group of antibiotics is relatively inactive against enterococci and these compounds are not usually considered for the treatment of enterococcal infections. However, combinations of aminoglycosides with penicillins can be shown to produce bactericidal synergy against many strains of enterococci, and combined penicillin/aminoglycoside therapy is recommended for the treatment of severe infections, notably enterococcal endocarditis (Garrod et al., 1973). Synergism is not always demonstrated in vitro by combinations of penicillins and aminoglycosides and is dependent upon the level of resistance of the organism to the aminoglycoside. Thus a number of strains of enterococci are highly resistant to streptomycin or kanamycin, and combinations of penicillin and streptomycin or penicillin and kanamycin are not synergistic against these strains (Standiford et al., 1970; Moellering et al., 1971; Russell and Sutherland, 1975).

The newer aminoglycosides, gentamicin and tobramycin, are more active in vitro than streptomycin and kanamycin against enterococci (Moeller-

Received for publication 20 September 1976 ing et al., 1973; Russell and Sutherland, 1975; Iannini et al., 1976), and amikacin, a semisynthetic derivative of kanamycin, is as active as kanamycin against these organisms (Iannini et al., 1976). Enterococci that are resistant to high levels of streptomycin or kanamycin are sensitive to these new aminoglycosides, and combined therapy with the new compounds and penicillins has been proposed for enterococcal infections (Moellering et al., 1971; Moellering et al., 1973; Ruhen and Darrell, 1973; Russell and Sutherland, 1975; Iannini et al., 1976).

There have been no reports in the literature of enterococci resistant to gentamicin, tobramycin or amikacin, but during a study in this laboratory of bacteria isolated from various hospitals during December 1975 it was observed that three cultures of Strep. faecalis were relatively resistant to gentamicin and tobramycin. It was also noted that amikacin failed to produce bactericidal synergy in combination with penicillins against kanamycin-resistant strains of Strep. faecalis. This report describes the sensitivities of recent isolates of Strep. faecalis to penicillins, aminoglycosides, and combinations of the compounds. 


\section{Material and methods}

\section{ANTIBIOTICS}

The penicillins tested were amoxycillin trihydrate and sodium benzylpenicillin (Beecham Pharmaceuticals) and the aminoglycosides were streptomycin sulphate (Glaxo Laboratories Ltd), kanamycin sulphate (Winthrop Laboratories), gentamicin sulphate (Roussell Laboratories Ltd), tobramycin sulphate (Eli Lilly and Co Ltd), and amikacin base (Bristol Laboratories).

\section{CULTURES}

The strains of enterococci tested were clinical isolates collected from three hospitals during December 1975 which had been cultured from a variety of sources (blood, urine, and wounds). The organisms were identified as group D streptococci by serotyping and were classified as strains of Strep. faecalis according to the criteria of Deibel (1964).

\section{MINIMUM INHIBITORY CONCENTRATIONS}

Antibacterial activity was measured by serial dilution of the antibiotics in $18 \mathrm{ml}$ volumes of $5 \%$ blood agar (Blood Agar Base, Oxoid; Defibrinated Horse Blood, Wellcome). Agar plates were inoculated with $0.001 \mathrm{ml}$ of an undiluted overnight culture of the test strain delivered with a multiple inoculating device (Dynatech Laboratories). Minimum inhibitory concentrations (MIC) were measured after incubation at $37^{\circ} \mathrm{C}$ for 18 hours.

\section{MINIMUM BACTERICIDAL CONCENTRATIONS OF AMOXYCILLIN/AMINOGLYCOSIDE COMBINATIONS}

Serial dilutions of amoxycillin were made in $4.5 \mathrm{ml}$ volumes of nutrient broth (Nutrient broth No. 2, Oxoid), and $0.5 \mathrm{ml}$ volumes of selected concentrations of the aminoglycosides were added to each tube. The aminoglycoside concentrations were selected as being levels attainable in the blood after usual dosage, and at these concentrations the compounds failed to demonstrate bactericidal activity against the test organisms. The tubes were inoculated with 0.03

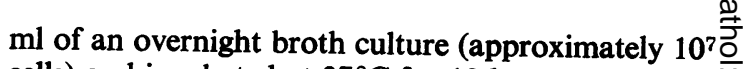
cells) and incubated at $37^{\circ} \mathrm{C}$ for 18 hours. A loopful of culture was taken from each tube not showing visible growth and streaked onto blood agar contain-O ing penicillinase (Difco). The plates were incubated overnight at $37^{\circ} \mathrm{C}$ and the minimum bactericidal $\frac{\bar{\sigma}}{\sigma}$ concentration (MBC) was recorded as the lowest $\stackrel{\oplus}{\stackrel{\oplus}{\varrho}}$ concentration of antibiotic from which subculture failed to yield viable colonies.

\section{BACTERICIDAL ACTIVITY}

Tubes of nutrient broth $(10 \mathrm{ml})$ containing known concentrations of the antibiotics were inoculated with $0.03 \mathrm{ml}$ of an 18-hour broth culture and incubated at $37^{\circ} \mathrm{C}$. Samples were taken at intervals and $0.02 \mathrm{ml}$ volumes of suitable dilutions were $\dot{\omega}$ pipetted onto blood agar containing penicillinase. $v$ Colonies were counted after incubation at $37^{\circ} \mathrm{C}$ for 옥 24 hours and the number of viable bacteria was estimated.

\section{Results}

MINIMUM INHIBITORY CONCENTRATIONS Results in Table 1 show the distribution of the minimum inhibitory concentrations of amoxycillin, benzylpenicillin, and various aminoglycosides against 34 recent clinical isolates of Strep. faecalis. Amoxycilin was the most active of the compounds and was two- to four-fold more active than benzylpenicillin. All cultures were sensitive to low concentrations of the penicillins. The aminoglycosides were notably less active than the penicillins, and the descending order of activity was tobramycin, gentamicin, kanamycin, amikacin, and streptomycin. Eight strains were highly resistant to both streptomycin and kanamycin (MIC values $>5000 \mu \mathrm{g} / \mathrm{ml}$ ) but these strains showed no increase in resistance to gentamicin, tobramycin, or amikacin. Another strain was highly resistant to streptomycin but was sensitive to kanamycin and the other compounds.

Three strains of Strep. faecalis were notably less sensitive to gentamicin than were the majority of strains, and the sensitivities of these organisms to the

Table 1 Distribution of minimum inhibitory concentrations of amoxycillin, benzylpenicillin, and aminoglycosides against 34 strains of Streptococcus faecalis

\begin{tabular}{|c|c|c|c|c|c|c|c|c|c|c|c|c|c|}
\hline \multirow[t]{2}{*}{ Antibiotic } & \multicolumn{13}{|c|}{ Minimum inhibitory concentration $(\mu \mathrm{g} / \mathrm{ml})$ and number of strains } \\
\hline & $0 \cdot 25$ & 0.5 & $1 \cdot 25$ & $2 \cdot 5$ & $5 \cdot 0$ & $12 \cdot 5$ & 25 & 50 & 125 & 250 & 500 & 1250 & $>5000$ \\
\hline $\begin{array}{l}\text { Amoxycillin } \\
\text { Benzylpenicillin } \\
\text { Streptomycin } \\
\text { Kanamycin } \\
\text { Gentamicin } \\
\text { Tobramycin } \\
\text { Amikacin }\end{array}$ & 30 & $\begin{array}{r}4 \\
17\end{array}$ & 13 & $\begin{array}{l}5 \\
3\end{array}$ & $\begin{array}{r}12 \\
8\end{array}$ & $\begin{array}{r}3 \\
11 \\
12 \\
1\end{array}$ & $\begin{array}{l}6 \\
2 \\
2 \\
2\end{array}$ & $\begin{array}{r}3 \\
11 \\
1 \\
1 \\
17\end{array}$ & $\begin{array}{r}16 \\
3 \\
2 \\
10\end{array}$ & $\begin{array}{l}2 \\
2 \\
1 \\
-\end{array}$ & $\begin{array}{l}\frac{3}{1} \\
3\end{array}$ & $\begin{array}{l}1 \\
3 \\
1\end{array}$ & $\begin{array}{l}9 \\
8\end{array}$ \\
\hline
\end{tabular}


Table 2 Minimum inhibitory concentrations of amoxycillin, benzylpenicillin, and aminoglycosides against clinical isolates and laboratory-selected strains of Strep. faecalis resistant to gentamicin or streptomycin

\begin{tabular}{|c|c|c|c|c|c|c|c|}
\hline \multirow[t]{3}{*}{ Antibiotic } & \multicolumn{7}{|c|}{ Minimum inhibitory concentration $(\mu \mathrm{g} / \mathrm{ml})$} \\
\hline & \multicolumn{4}{|c|}{ Clinical isolates } & \multicolumn{3}{|c|}{ Laboratory-selected strains } \\
\hline & C134 & C135 & $W 464$ & Control ${ }^{1}$ C36 & $\begin{array}{l}\text { C90 } \\
\text { parent }\end{array}$ & $\begin{array}{l}\text { C90 } \\
S \text { res }\end{array}$ & $\begin{array}{l}C 90 \\
G \text { res }^{2}\end{array}$ \\
\hline $\begin{array}{l}\text { Amoxycillin } \\
\text { Benzylpenicillin } \\
\text { Streptomycin } \\
\text { Kanamycin } \\
\text { Gentamicin } \\
\text { Tobramycin } \\
\text { Amikacin }\end{array}$ & $\begin{array}{c}0 \cdot 25 \\
0 \cdot 5 \\
500 \\
1250 \\
250 \\
125 \\
500\end{array}$ & $\begin{array}{c}0 \cdot 25 \\
0 \cdot 5 \\
500 \\
1250 \\
250 \\
125 \\
500\end{array}$ & $\begin{array}{c}0.25 \\
1 \cdot 25 \\
1250 \\
1250 \\
500 \\
250 \\
1250\end{array}$ & $\begin{array}{c}0 \cdot 25 \\
0 \cdot 5 \\
>5000 \\
>5000 \\
5 \cdot 0 \\
5 \cdot 0 \\
50\end{array}$ & $\begin{array}{c}0 \cdot 25 \\
1 \cdot 0 \\
50 \\
50 \\
10 \\
10 \\
125\end{array}$ & $\begin{array}{c}0.25 \\
0.5 \\
>5000 \\
50 \\
10 \\
10 \\
125\end{array}$ & $\begin{array}{l}0 \cdot 25 \\
0 \cdot 25 \\
125 \\
500 \\
250 \\
100 \\
2500\end{array}$ \\
\hline
\end{tabular}

Streptomycin, kanamycin resistant.

'Streptomycin resistant, selected after three subcultures in vitro in the presence of streptomycin.

${ }^{3}$ Gentamicin resistant, selected after three subcultures in vitro in the presence of gentamicin.

aminoglycosides are shown in Table 2 . Two of the strains, C134 and C135 isolated from different sites in the same patient, showed the same characteristics and were regarded as being the same organism. The third strain, W464, was isolated from a patient at a different hospital. Both patients had been treated with topical gentamicin for the treatment of leg infections. The three strains were 50- to 100 -fold less sensitive to gentamicin than was a control sensitive strain and required 250 to $500 \mu \mathrm{g}$ gentamicin $/ \mathrm{ml}$ for inhibition of growth in these tests. These strains also showed a reduced sensitivity to the other aminoglycosides, but the reduction in sensitivity to streptomycin, kanamycin, and amikacin was lower than that seen with gentamicin or tobramycin.

The extent of the cross-resistance observed among the aminoglycosides against the clinical isolates resistant to gentamicin was similar to that seen with gentamicin-resistant strains selected in vitro by cultivation in the presence of gentamicin. Thus results in Table 2 show the sensitivities of a strain of Strep. faecalis C90, sensitive to streptomycin and gentamicin, and of cultures of this strain selected after three subcultures in the presence of streptomycin or gentamicin. The cultures isolated after exposure to streptomycin showed a high level of resistance to streptomycin (MIC $>5000 \mu \mathrm{g} / \mathrm{ml}$ ) but displayed no increase in resistance to the other aminoglycosides. In contrast, the strain cultured in the presence of gentamicin showed a moderate level of resistance to gentamic in (MIC250 $\mu \mathrm{g} / \mathrm{ml}$ ) and also demonstrated an increase in resistance to the other aminoglycosides.

Attempts to demonstrate transfer of gentamicinresistance from Strep. faecalis $\mathrm{C} 134$ and Strep. faecalis W464 to a plasmid-free recipient strain of Strep. faecalis (JH2-2) (Jacob and Hobbs, 1974) were unsuccessful, although haemolysin production, which is known to be plasmid-mediated (Jacob et al., 1975) was transferred from Strep. faecalis C134 to the recipient strain in these tests. Also no loss of gentamicin resistance was observed after growth of the cultures in the presence of ethidium bromide, acridine-orange or incubation at $44^{\circ} \mathrm{C}$, under which conditions haemolysin production was eliminated from Strep. faecalis C134. In contrast, transfer of streptomycin and kanamycin resistance was demonstrated from strains of Strep. faecalis with high level resistance (MIC $>5000 \mu \mathrm{g} / \mathrm{ml}$ ) to the recipient strain of Strep. faecalis JH2-2 under the same conditions.

BACTERICIDAL SYNERGISM STUDIES

The results of tests to determine the minimum bactericidal concentrations (MBC) of combinations of amoxycillin and the aminoglycosides against a number of clinical isolates of Strep. faecalis of different aminoglycoside sensitivities are shown in Table 3. Amoxycillin was ineffective in these tests (MBC $>100 \mu \mathrm{g} / \mathrm{ml}$ ), but in combination with sublethal concentrations of the aminoglycosides, amoxycillin $\mathrm{MBC}$ values $(5.0 \mu \mathrm{g} / \mathrm{ml})$ against the aminoglycoside sensitive strain of Strep. faecalis (T1089) were not greatly in excess of inhibitory concentrations ( $c a 1.0 \mu \mathrm{g} / \mathrm{ml}$ ). Against the streptomycinresistant strain $\mathrm{C} 119$, the amoxycillin/streptomycin combination was not bactericidal but the other combinations were as effective against this strain as against the sensitive strain, T1089. Similarly, the amoxycillin/streptomycin and amoxycillin/kanamycin combinations failed to demonstrate bactericidal activity against the streptomycin/kanamycin resistant strain of Strep. faecalis C36. Unexpectedly, the MBC of the amoxycillin/amikacin combination was in excess of $100 \mu \mathrm{g}$ amoxycillin/ml $+20 \mu \mathrm{g}$ amikacin/ $\mathrm{ml}$, although the organism showed typical sensitivity to amikacin in the growth inhibition tests (MIC 50 $\mu \mathrm{g} / \mathrm{ml})$. Similar results were obtained in tests with the other seven kanamycin-resistant strains isolated in this study, and amoxycillin/amikacin and benzyl- 
Table 3 Minimum bactericidal concentrations of amoxycillin, alone, and in combination with aminoglycosides, against aminoglycoside-resistant strains of Streptococcus faecalis

\begin{tabular}{|c|c|c|c|c|}
\hline \multirow{2}{*}{$\begin{array}{l}\text { Amoxycillin/aminoglycoside } \\
\text { combination }\end{array}$} & \multicolumn{4}{|c|}{ Minimum bactericidal concentration ( $\mu \mathrm{g} /$ amoxycillin/ml) } \\
\hline & $\begin{array}{l}\text { T10891 } \\
\text { (sens) }\end{array}$ & $\begin{array}{l}\text { C119 } \\
\text { (S res) }\end{array}$ & $\begin{array}{l}\text { C36 } \\
(S K \text { res })\end{array}$ & $\begin{array}{l}C 134 / W 464 \\
(G \text { res })\end{array}$ \\
\hline $\begin{array}{l}\text { Amoxycillin alone } \\
+ \text { streptomycin }(20)^{2} \\
+ \text { kanamycin }(20)^{2} \\
+ \text { gentamicin }(5 \cdot 0)^{2} \\
\text { + tobramycin }(5 \cdot 0)^{2} \\
\text { + amikacin }(20)^{2}\end{array}$ & $\begin{array}{r}>100 \\
5 \cdot 0 \\
5 \cdot 0 \\
5 \cdot 0 \\
5 \cdot 0 \\
5 \cdot 0\end{array}$ & $\begin{array}{r}>100 \\
>100 \\
5 \cdot 0 \\
1 \cdot 0 \\
1 \cdot 0 \\
5.0\end{array}$ & $\begin{array}{r}>100 \\
>100 \\
>100 \\
5 \cdot 0 \\
1 \cdot 0 \\
>100\end{array}$ & \begin{tabular}{r|}
$>100$ \\
$5 \cdot 0^{3}$ \\
$5 \cdot 0^{3}$ \\
$5 \cdot 0^{3}$ \\
$5 \cdot 0^{3}$ \\
$5 \cdot 0^{3}$
\end{tabular} \\
\hline
\end{tabular}

IStrain number.

${ }^{2}$ Aminoglycoside concentration $(\mu \mathrm{g} / \mathrm{ml})$; the aminoglycosides were ineffective at these concentrations.

S, streptomycin; K, kanamycin; G, gentamicin.

${ }^{3}$ Growth often occurred on subculture from tubes containing higher concentrations.

Table 4 Bactericidal activities of amoxycillin alone and in combination with aminoglycosides in duplicate tests against gentamicin-resistant strains of Streptococcus faecalis

\begin{tabular}{|c|c|c|c|c|c|c|c|c|}
\hline \multirow{3}{*}{$\begin{array}{l}\text { Amoxycillin/aminoglycoside } \\
\text { combination }\end{array}$} & \multicolumn{8}{|c|}{ Viable count after $24 \mathrm{~h}$ at $37^{\circ} \mathrm{C}(\mathrm{cells} / \mathrm{ml})$} \\
\hline & \multicolumn{2}{|c|}{ Strain C134 } & \multicolumn{2}{|c|}{ Strain C135 } & \multicolumn{2}{|c|}{ Strain W464 } & \multicolumn{2}{|c|}{ Control strains } \\
\hline & 1 & 2 & 1 & 2 & 1 & 2 & $T 1089^{2}$ & $T 1101^{8}$ \\
\hline $\begin{array}{l}\text { Amoxycillin }(2 \cdot 5)^{1} \text { alone } \\
+ \text { streptomycin }(20)^{1} \\
+ \text { kanamycin }(20) \\
\text { + gentamicin }(5 \cdot 0) \\
\text { + tobramycin }(5 \cdot 0) \\
\text { + amikacin }(20)\end{array}$ & $\begin{array}{r}>100 \\
40 \\
0 \\
0 \\
1 \\
0\end{array}$ & $\begin{array}{r}350 \\
200 \\
50 \\
40 \\
80 \\
35\end{array}$ & $\begin{array}{r}>100 \\
2 \\
>100 \\
>100 \\
80 \\
75\end{array}$ & $\begin{array}{r}200 \\
0 \\
0 \\
100 \\
13 \\
0\end{array}$ & $\begin{array}{r}>100 \\
70 \\
0 \\
0 \\
1 \\
10\end{array}$ & $\begin{array}{r}250 \\
750 \\
15 \\
11 \\
36 \\
70\end{array}$ & $\begin{array}{r}>100 \\
0 \\
0 \\
0 \\
0 \\
0\end{array}$ & $\begin{array}{r}200 \\
200 \\
>100 \\
0 \\
0 \\
450\end{array}$ \\
\hline
\end{tabular}

${ }^{1}$ Concentration $(\mu \mathrm{g} / \mathrm{ml})$; the aminoglycosides were ineffective at these concentrations.

Aminoglycoside-sensitive.

${ }^{3}$ Resistant to streptomycin and kanamycin.

penicillin/amikacin combinations failed to produce synergistic bactericidal effects against any of the kanamycin-resistant (amikacin-sensitive) strains of Strep. faecalis. There was no evidence of crossresistance with the amoxycillin/gentamicin and amoxycillin/tobramycin combinations against the kanamycin-resistant strain Strep. faecalis C36, and both combinations produced marked bactericidal activity against this strain and other kanamycinresistant enterococci.

The gentamicin-resistant isolates responded in a more variable fashion to amoxycillin/aminoglycoside combinations in the bactericidal tests compared with gentamicin-sensitive strains. In the MBC tests, sensitive strains gave a sharp end-point so that no growth was observed on subculture from combinations containing amoxycillin at concentrations of $5.0 \mu \mathrm{g} / \mathrm{ml}$ or more. With the gentamicin-resistant strains there was no growth from cultures containing $5.0 \mu \mathrm{g}$ amoxycillin $/ \mathrm{ml}$ or $10 \mu \mathrm{g}$ amoxycillin $/ \mathrm{ml}$ in combination with the aminoglycosides but growth sometimes occurred in subcultures from tubes containing higher concentrations of amoxycillin. In the viable count tests, gentamicin-sensitive strains of Strep. faecalis were always sterilised by combinations of $2.5 \mu \mathrm{g}$ amoxycillin plus $5.0 \mu \mathrm{g}$ gentamicin $/ \mathrm{ml}$ whereas, with the gentamicin-resistant strains, on some occasions the cultures were made sterile, but on repeat tests viable bacteria were often recovered (Table 4). Similar variable responses were observed with combinations containing other aminoglycosides.

\section{Discussion}

The results reported here for a limited number of recent clinical isolates of Strep. faecalis show the prevalence of a relatively high proportion of strains with reduced sensitivity to aminoglycoside antibiotics. Strains resistant to streptomycin or kanamycin demonstrated a high level of resistance to the compounds but were sensitive to gentamicin, tobramycin or amikacin. In contrast, the strains with reduced sensitivity to gentamicin showed a moderate level of resistance to gentamicin and to the other aminoglycosides.

Enterococci with a high level of resistance to streptomycin have been known for some time (Havard et al., 1959), and more recent reports have described a relatively high incidence of resistance to streptomycin and kanamycin (Standiford et al., 
1970; Moellering et al., 1971; Ruhen and Darrell, 1973; Iannini et al., 1976). In this study, the streptomycin-resistant strains of Strep. faecalis isolated in 1975 were almost always resistant to kanamycin which contrasts with the results of earlier studies reported from this laboratory. For example, none of 10 streptomycin-resistant strains of Strep. faecalis isolated in 1961 and only two of 15 streptomycinresistant strains isolated in 1967 were resistant also to kanamycin (Sutherland and Rolinson, 1964; Russell and Sutherland, 1975). The apparent increase in the proportion of kanamycin-resistant strains relative to streptomycin-resistant strains observed here may be a reflection of increased usage of kanamycin, but the number of strains tested was very small.

Enterococci with a high level of resistance to streptomycin or kanamycin have been shown to be sensitive to gentamicin, tobramycin, and amikacin (Iannini et al., 1976), and bactericidal synergy has been demonstrated by a combination of penicillins and gentamicin or tobramycin against these resistant strains (Moellering et al., 1971; Moellering et al., 1973; Ruhen and Darrell, 1973; Russell and Sutherland, 1975). The results of this study are in agreement with these reports but the failure to demonstrate synergism with penicillin/amikacin combinations against kanamycin-resistant strains of Strep. faecalis was unexpected in view of the apparent sensitivity of these organisms to amikacin. Amikacin/ penicillin combinations produce synergistic effects against kanamycin-sensitive strains, and the lack of synergy against kanamycin-resistant strains is evidence of cross-resistance between kanamycin and amikacin which is not observed in growth-inhibition tests.

Gentamicin-resistant enterococci have not been reported previously in the literature, and the strains described here do not show the high level of resistance which is characteristic of streptomycin and kanamycin-resistant enterococci. Nevertheless the concentrations of gentamicin required to inhibit growth of the two cultures of Strep. faecalis (250 to $500 \mu \mathrm{g} / \mathrm{ml}$ ) were notably higher than the levels required to inhibit the majority of strains $(5 \cdot 0-12 \cdot 5$ $\mu \mathrm{g} / \mathrm{ml})$. Moreover, the variable results obtained in the bactericidal tests with these two strains contrasted with the uniform bactericidal synergy observed with combinations of amoxycillin and gentamicin against sensitive strains of Strep. faecalis. The rationale for the use of penicillin/ aminoglycoside combinations in the treatment of enterococcal infections has been largely based upon the fact that such combinations can sterilise cultures of enterococci in vitro (Garrod et al., 1973), but with these gentamicin-resistant strains this effect was not always observed.
The characteristics of the gentamicin-resistant clinical isolates, namely, the moderate level of resistance and degree of cross-resistance with other aminoglycosides, were markedly similar to those of the resistant strains selected in vitro after subculture in the presence of gentamicin. These findings, coupled with the failure to demonstrate conjugal transfer of resistance or to eliminate resistance with curing agents, suggest that the strains might have arisen in vivo by selection as a result of therapy with topical gentamicin, as has been reported for Pseudomonas aeruginosa (Snelling et al., 1971; Holmes et al., 1974) and, more recently, for Staphylococcus aureus (Porthouse et al., 1976; Warren and Roberts,1976).

Therapy with benzylpenicillin and streptomycin has often been recommended as the treatment of choice for severe enterococcal infections but awareness of the increasing incidence of streptomycin and kanamycin-resistant strains has led to an increased interest in the activity of combinations of penicillins with newer aminoglycosides, namely, gentamicin, tobramycin, and amikacin. The finding of strains that are apparently less sensitive to these compounds emphasises the need for appropriate laboratory tests for the selection of the most suitable penicillin/ aminoglycoside combination for therapy of enterococcal infections.

We are grateful to Dr A. E. Jacob for providing the plasmid-free strain of Strep. faecalis JH2-2.

\section{References}

Deibel, R. H. (1964). The group D streptococci. Bact. Rev., 28, 330-366.

Garrod, L. P., Lambert, H. P., and O'Grady, F. (1973). Antibiotic and Chemotherapy, 4th edition, p. 311. Churchill Livingstone, Edinburgh and London.

Havard, C. W. H., Garrod, L. P., and Waterworth, P. M. (1959). Deaf or dead? A case of subacute bacterial endocarditis treated with penicillin and neomycin. Brit. med. J., 1, 688-689.

Holmes, R. K., Minshew, B. H., Gould, K., and Sanford, J. P. (1974). Resistance of Pseudomonas aeruginosa to gentamicin and related aminoglycoside antibiotics. Antimicrob. Agents Chemother., 6, 253-262.

Iannini, P. B., Ehret, J., and Eickhoff, T. C. (1976). Effects of ampicillin-amikacin and ampicillin-rifampin on enterococci. Antimicrob. Agents Chemother., 9, 448-451.

Jacob, A. E., Douglas, G. J., and Hobbs, S. J. (1975). Self-transferable plasmids determining the hemolysin and bacteriocin of Streptococcus faecalis var. zymogenes. J. Bact., 121, 863-872.

Jacob, A. E. and Hobbs, S. J. (1974). Conjugal transfer of plasmid-borne multiple antibiotic resistance in Streptococcus faecalis var. zymogenes. J. Bact., 117, 360-372.

Moellering, R. C. Jr., Wennersten, C., Medrek, T., and Weinberg, A. N. (1971). Prevalence of high-level resis- 
tance to aminoglycosides in clinical isolates of enterococci. Antimicrob. Agents Chemother., 1970, 335-340.

Moellering, R. C. Jr., Wennersten, C., and Weinstein, A. J. (1973). Penicillin-tobramycin synergism against enterococci: a comparison with penicillin and gentamicin. Antimicrob. Agents Chemother., 3, 526-529.

Porthouse, A., Brown, D. F. J., Graeme Smith, R., and Rogers, T. (1976). Gentamicin resistance in Staphylococcus aureus. Lancet, 1, 20-21.

Ruhen, R. W. and Darrell, J. H. (1973). Antibiotic synergism against group D streptococci in the treatment of endocarditis. Med. J. Aust., 2, 114-116.

Russell, E. J. and Sutherland, R. (1975). Activity of amoxycillin against enterococci and synergism with aminoglycoside antibiotics. J. med. Microbiol., 8, 110.

Snelling, C. F. T., Ronald, A. R., Cates, C. Y., and Forsythe, W. C. (1971). Resistance of Gram-negative bacilli to gentamicin. J. infect. Dis., 124, Supplement, 264-270.

Standiford, H. D., de Maine, J. B., and Kirby, W. M. M. (1970). Antibiotic synergism of enterococci. Arch. intern. Med., 126, 255-259.

Sutherland, R. and Rolinson, G. N. (1964). Activity of ampicillin in vitro compared with other antibiotics. $J$. clin. Path., 17, 461-465.

Warren, R. E., and Roberts, S. O. B. (1976). Gentamicinresistant staphylococci (Letter). Lancet, 1, 543-544. 